\title{
Analisis Kesulitan Pembelajaran Matematika Secara Daring pada Kelas V SDN 3 Pelangan Tahun Pelajaran 2020/2021
}

\author{
Ketut Puspita Ningrum ${ }^{1}$,Sudirman ${ }^{2}$, Muhammad Turmuzi ${ }^{3}$ \\ ${ }^{123}$ Pendidikan Guru Sekolah Dasar, FKIP, Universitas Mataram \\ Email: ketutpuspita23@gmail.com¹, sudirman_fkip@unram.ac.id ${ }^{2}, \underline{\text { tur.muzi@ yahoo.co.id }}$
}

\begin{abstract}
This study aims to describe the difficulties of learning mathematics online in class V SDN 3 Pelalang for the 2020/2021 academic year. The difficulty is seen from the preparation, implementation, and evaluation. The type of research used is descriptive qualitative research with case study method. Data collection techniques using semi-structured interviews and documentation. Data analysis used the Milles and Huberman models, namely data collection, data reduction, data presentation, and drawing conclusions. The results of the study: 1) Difficulty in preparing mathematics online learning. 2) Difficulties in implementing online learning mathematics. 3) Difficulty in evaluating mathematics online learning.
\end{abstract}

Keywords: Difficulty, learning, mathematics, online, Class V

\begin{abstract}
Abstrak
Penelitian ini bertujuan untuk mendeskripsikan kesulitan pembelajaran matematika secara daring pada kelas V SDN 3 Pelangan tahun pelajaran 2020/2021. Kesulitan tersebut dilihat dari persiapan, pelaksanaan, dan evaluasi. Jenis penelitian yang digunakan adalah penelitian kualitatif deskriptif dengan metode studi kasus. Tehnik pengumpulan data dengan menggunakan wawancara semi struktur dan dokumentasi. Analisis data menggunakan model Milles dan Huberman yaitu koleksi data, reduksi data, penyajian data, dan penarikan kesimpulan. Hasil penelitian: 1) Kesulitan persiapan pembelajaran daring matematika. 2) Kesulitan pelaksanaan pembelajaran daring matematika. 3) Kesulitan evaluasi pembelajaran daring matematika.
\end{abstract}

Kata Kunci: Kesulitan, pembelajaran, daring, matematika, Kelas V

\section{PENDAHULUAN}

Matematika adalah salah satu mata pelajaran yang menduduki peran yang sangat penting dalam dunia pendidikan, hal tersebut dapat dilihat dari kegunaan matematika itu sendiri dalam kehidupan sehari-hari karena matematika bukanlah ilmu pengetahuan yang hanya dapat bermanfaat bagi dirinya sendiri melainkan juga dapat bermanfaat bagi ilmuilmu lainnya, seperti ilmu sains dan teknologi, sehingga matematika sangatlah penting diajrakan mulai dari pendidikan dasar, yakni pada jenjang Sekolah Dasar (SD). Dalam kurikulum 2013 mata pelajaran matematika khususnya untuk kelas tinggi dipisahkan dari pembelajaran tematik terpadu atas pertimbangan tertentu. Mata pelajaran matematika pada buku tematik terpadu dirasa kedalaman materinya masih terlalu rendah, sehingga siswa tidak dapat menerima pemahaman konsep secara optimal, dengan demikian matematika menggunakan buku secara terpisah dari mata pelajaran lainnya.

Berdasarkan hasil penelitain yang dilakukan oleh Yuliza Putri Utami, dkk dengan hasil penelitian yakni aplikasi e-learning (daring) terlalu sulit kemungkinan siswa tidak mampu belajar matematika secara maksimal, begitupula ketika banyaknya data yang harus tersampaikan tetapi akses internet atau jaringan menjadi lambat, tentu saja hal tersebut akan mengganggu aktivitas pembelajaran siswa, khususnya dalam proses pembelajaran matematika yang dilakukan secara daring.

Sejalan dengan hasil observasi empirik yang dilakukan oleh peneliti di SDN 3 Pelangan tanggal 4 Januari 2021 pada guru kelas V di SDN 3 Pelangan, didapatkan bahwa pembelajaran matematika pada SDN 3 Pelangan telah dilakukan secara daring. Namun dalam pembelajaran matematika yang dilakukan pada SDN 3 Pelangan ini masih belum memenuhi standar yang diharapkan, baik untuk guru maupun untuk sekolah, hal tersebut dapat dilihat dari rata-rata nilai matematika siswa masih terbilang rendah dibandingkan dengan mata pelajaran pokok lainnya seperti bahasa Indonesia, nilai matematika ini masih terbilang rendah terutama pada kelas V. Diketahui bahwa KKM pada mata pelajaran matematika adalah 
75 dengan jumlah siswa kelas V yakni 28 orang, dan dari jumlah siswa yang terdapat pada kelas $\mathrm{V}$ terdapat $60 \%$ siswa yang mendapatkan nilai dibawah KKM dan $40 \%$ siswa yang sudah mendapatkan nilai diatas KKM. Agar dapat mengatasi persoalan tersebut perlunya diteliti lebih mendalam terkait kesulitan-kesulitan yang terjadi pada pembelajaran matematika khususnya pada kelas V khususnya pada perencanaan, pelaksanaan dan evaluasi dalam pemblajaran daring matematika kelas V semester genap di SDN 3 Pelangan tahun pelajaran 2020/2021.

\section{METODE}

Jenis penelitian yang digunakan dalam penelitian ini adalah kualitatif deskriptif. Kualitatif deskriptif merupakan data yang diperoleh dari hasil pengamatan, wawancara, studi dokumentasi, analisis dokumen, catatan lapangan dan lain-lain disusun peneliti dilokasi penelitian tidak dituangkan dalam bentuk data numerik melainkan dituangkan dalam deskripsi kata-kata (Mardawani, 2020: 17). Yang menjadi sumber data dalam penelitian ini ialah guru kelas V di SDN 3 Pelangan, dengan meneliti kesulitan pembelajaran daring matematika pada semester genap tahun pelajaran 2020/2021., dan yang menjadi objek dalam penelitian ini adalah kesulitan pembelajaran matematika secara daring.

Adapun tehnik pengumpuan data yang digunakan dalam penelitian ini adalah wawancara semi struktur dan dokumentasi. Wawancara digunakan untuk memperoleh informasi dan teknik pengumpulan data yang mempunyai tujuan untuk mendalami suatu kejadian atau kegiatan subjek penelitian (Andriani, 2020: 20) sedangkan dokumentasi adalah rekaman atau kejadian yang ditulis atau dicetak. Yang dapat berupa catatan anekdot, surat, buku harian, dan dokumen-dokumen lainnya (Andriani, 2020: 21). Tehnik analisis data menggunakan model Milles dan Huberman yaitu koleksi data, reduksi data, penyajian data, dan penarikan kesimpulan. Uji keabsahan data yang digunakan dalam penelitian ini adalah uji credibility (kepercayaan) menggunakan triangulasi (triangulasi sumber, triangulasi teknik, dan triangulasi waktu) dan member check.

\section{HASIL DAN PEMBAHASAN}

. Berdasarkan hasil penelitian yang telah dipaparkan di atas, maka pembahasan yang akan dibahas adalah temuan dan masalah yang telah ditemukan oleh peneliti ketika melakukan penelitian. Adapun bahasan yang akan dibahas adalah (1) Kesulitan persiapan pembelajaran daring matematika yang meliputi kesulitan pemilihan media pembelajaran daring matematika dan kesulitan dalam fasilitas pembelajaran daring matematika yakni kesulitan pada handphone android, kesulitan dalam kuota internet dan kesulitan pada koneksi jaringan, (2) Kesulitan dalam pelaksanaan pembelajaran daring matematika yang meliputi kesulitan dalam mengordinasi peserta didik ketika pelaksanaan pembelajaran daring matematika berlangsung, dan (3) Kesulitan dalam evaluasi pembelajaran daring matematika yang meliputi kesulitan dalam melakukan penilaian.

\section{Kesulitan dalam Persiapan Pembelajaran Daring Matematika}

Terdapat dua kesulitan dalam persiapan pembelajaran daring matematika, yakni kesulitan dalam pemilihan media dan kesulitan dalam mempersiapkan fasilitas pembelajaran daring matematika. Berikut pemaparannya:

\section{1) Kesulitan dalam Pemilihan Media Pembelajaran Daring Matematika}

Kesulitan pemilihan media merupakan salah satu kendala yang meyebabkan pembelajaran menjadi terhambat dikarenakan peranan media pembelajaran sangat penting untuk memudahkan peserta didik dalam memahami materi yang diajarkan. Menurut Miftah (98: 2013) media pembelajaran merupakan sesuatu atau bisa berupa alat, bahan, atau keadaan yang digunakan sebagai perantara komunikasi yang digunakan dalam kegiatan pembelajaran. Media pembelajaran sangat efektif untuk digunakan dalam menyampaikan materi pelajaran, diantara manfaatnya yaitu mengurangi verbalisme sehingga kegiatan belajar mengajar lebih bervariatif, informasi dari materi yang diajarkan dapat tersampaikan dengan lebih baik, dapat meningkatkan pemahaman materi pelajaran 
sehingga dapat dengan mudah mencapai tujuan pembelajaran (Setyowati, 2020: 124).

Kesulitan pemilihan media yang dirasakan oleh guru kelas V di SDN 3 Pelangan adalah kesulitan pemilihan media yang akan digunakan dalam pelaksanaan pembelajaran daring matematika. Faktor penghambat dari kesulitan guru dalam pemilihan media ini dikarenakan ketidaktersediaan media pembelajaran, hal ini disebabkan ketidakmampuan wali murid untuk menyediakan media pembelajaran dirumah serta tidak ada persiapan baik dari orang tua maupun dari peserta didik sendiri. Adapun cara guru mengatasi kesulian tersebut dengan menggantikan media pembelajaran dengan video pembelajaran yang dibuat sendiri kemudian dibagikan kepada peserta didik sebagai pengganti media pembelajaran khususnya pada mata pelajaran matematika.

\section{2) Kesulitan dalam Fasilitas Pembelajaran Daring Matematika}

Kesulitan dalam fasilitas pembelajaran daring matematika seperti handphone android, kuota internet dan koneksi jaringan.

\section{a. Handphone Android}

Handphone android merupakan salah satu alat teknologi yang dapat menghubungkan komunikasi pada jarak jauh, tentunya handphone android ini merupakan alat komunikasi yang dapat digunakan untuk melaksanakan pembelajaran secara daring. Pemanfaatan handphone android sebagai penunjang belajar semenjak setahun terakhir sangat memberikan efek positif terhadap siswa, kehadiran handphone android di sekolah sangat bagus untuk meningkatkan motivasi belajar siswa baik pelajaran PAI maupun pelajaranpelajaran umum lainnya ( Prakoso, 2019:66).

Kesulitan guru dalam pelaksanaan pembelajaran daring matematika pada kelas $\mathrm{V}$ di SDN 3 Pelangan terkait kesulitan dalam fasilitas pembelajaran daring matematika yang pertama adalah kesulitan pada fasilitas handphone android yang akan digunakan untuk melaksanakan pembelajaran daring khususnya untuk pembelajaran daring matematika. Faktor penghambat dalam kesulitan handphone android ini dikarenakan ketidakmampuan wali murid untuk menyediakan fasilitas, hal tersebut terjadi karena faktor ekonomi peserta didik, rata-rata wali murid berprofesi sebagai petani dan buruh, sehingga wali murid belum sepenuhnya mampu memfasilitasi peserta didik. Sehubungan dengan hal tersebut, guru dan sekolah mencari alternatif lain agar kesulitan ini dapat terselesaikan atau cara mengatasi yakni dengan menyediakan handphone android kepada peserta didik khususnya untuk kelas tinggi, sehingga kesulitan persiapan pembelajaran daring matematika ini dapat sedikit teratasi.

\section{b. Kuota Internet}

Kuota internet merupakan batasan pemakaian internet pada waktu tertentu. Kuota internet erat kaitannya dengan handphone android, dengan adanya kouta internet maka handphone android akan dapat mengakses berbagai informasi. Kesulitan dalam kuota internet pada peserta didik kelas V di SDN 3 Pelangan ini juga di faktori oleh ekonomi orang tua setai peserta didik. Meskipun kuota internet sudah disediakan oleh pihak sekolah, namun tidak sedikit siswa yang kehabisan kuota internet sebelum waktu yang telah ditentukan, dikarenakan banyak peserta didik yang membuka youtube untuk menambah pemahaman mereka terkait materi yang diajarkan, sehingga inilah yang menjadi faktor penghambat siswa dalam kuota internet. Sehubungan dengan faktor ekonomi wali peserta didik, sehingga cara guru dan pihak sekolah mengatasi kesulitan kuota internet ini adalah dengan membagiakan kuota internet untuk setiap bulannya.

\section{c. Koneksi Jaringan}

Koneksi jaringan adalah hal yang vital terutama untuk terciptanya pembelajaran secara garis penuh, dikarenakan pembelajaran harus diakses melalui internet tanpa ada koneksi internet, tidak akan ada interaksi yang sifatnya langsung antara siswa dan guru (Hamdani, 2020: 7). Letak wilayah tempat tinggal sangat mempengaruhi sinyal, Hal ini sejalan dengan hasil penelitian yang dilakukan oleh Rigianti (2020: 299) menyatakan bahwa kebutuhan koneksi internet menjadi hal yang sangat penting dalam pelaksanaan pembelajaran daring.

Yang menjadi faktor penghambat pada kelas V di SDN 3 Pelangan dalam kesulitan koneksi jaringan disebabkan oleh letak 
geografis rumah peserta didik yang belum sepenuhnya terjangkau oleh koneksi jaringan internet yang memadai, sehingga pembelajaran menjadi terputus-putus. Adapun cara mengatasi kesulitan koneksi jaringan ini adalah dengan meminta peserta didik untuk mencari lokasi sekitar rumah yang sekiranya memiliki koneksi jaringan yang bagus, agar pembelajaran tetap dapat terlaksana, meskipun cara tersebut juga belum sepenuhnya dapat mengatasi kesulitan koneksi jaringan secara maksimal.

Kesulitan dalam Pelaksanaan Pembelajaran Daring Matematika

Kesulitan dalam pelaksanaan pembelajaran daring matematika pada kelas V di SDN 3 Pelangan oleh guru kelas V ketika diwawancara oleh peneliti menjelaskan bahwa kesulitan pada pelaksanaan tentuya juga memiliki kendala atau kesulitan, adapun kesulitan yang dialamai oleh guru kelas $\mathrm{V}$ yakni pada saat mengordinasi peserta didik pada saat jam pelajaran matematika dilaksanakan.

1) Kesulitan dalam Mengordinasi pada Pelaksanaan Pembelajaran Daring Matematika

Hasil wawancara menunjukkan bahwa kesulitan guru dalam pelaksanaan pembelajaran daring terletak pada kesulitan guru dalam mengordinasi peserta didik pada saat pembelajaran daring matematika terlaksana. Adapun yang menjadi faktor penghambat dalam kesulitan ini dikarenakan guru tidak dapat secara langsung dan secara leluas dalam memantau peserta didik selama pelaksanaan pembelajaran daring khususnya matematika, hal tersebut terjadi karena pembelajaran matematika membutuhkan tenaga besar dalam menjelaskan materi kepada peserta didik, sehingga pada kegiatan pembelajaran matematika dilakukan secara daring tidak memungkinkan guru untuk memantau satu-persatu peserta didik, hal ini juga dipengarruhi oleh banyaknya peserta didik yang tidak mengikuti pelaksanaan pembelajaran daring matematika disebabkan oleh kendala fasilitas dan lain sebagainya. cara guru mengatasi kesulitan tersebut, berdasarkan hasil wawancara pada guru kelas $\mathrm{V}$ di SDN 3 Pelangan cara mengatasi permasalahan dalam mengordinasi peserta didik ialah dengan melaksanakan pembelajaran secara luring seminggu sekali dengan membentuk kelompok kecil, sehingga pada pelaksanaan pembelajaran secara luring guru dapat memantau secara detail dan juga dapat mengatur serta mengarahkan pelaksanaan pembelajaran yang akan dilakukan secara online dan secara offline.

\section{Kesulitan dalam Evaluasi Pembelajaran Daring Matematika}

Evaluasi pembelajaran merupakan bagian integral dari proses pembelajaran, artinya dalam pembelajaran akan melibatkan tiga aktivitas, yakni perencanaan, pelaksanaan, dan evaluasi (Rahmawati, 2009 :95). Dalam melakukan evaluasi hasil belajar peserta didik dituntut dalam mengevaluasi secara menyeluruh terhadap peserta didik, baik dari segi pemahaman materi atau bahan pelajaran yang telah diberikan, maupun dari segi penghayatan dan pengalamannya (Rahmawati, 2009 :97).

Kesulitan dalam evaluasi pembelajaran daring matematika pada kelas V di SDN 3 Pelangan ialah kesulitan dalam melakukan penilaian, yang menjadi faktor penghambat guru dalam melakukan penilaian dikarenakan guru tidak mengetahui kebenaran kemampuan siswa dalam mengerjakan semua tugas matematika yang diberikan secara daring. Hal tersebut dapat diketahui dari hasil penilaian yang tidak sesuai dengan hasil pembelajaran pada saat dilaksanakan secara luring. Ketika tugas yang diberikan secara daring, jawaban peserta didik rata-rata benar, namun beda halnya ketika pembelajaran dilakukan secara luring, masih ada beberapa peserta didik yang masih belum sepenuhnya dapat mengerjakan tugas yang diberikan oleh guru. Adapun cara guru mengatasi kendala atau kesulitan ini ialah dengan melakukan penilaian pada saat pembelajaran secara luring, sehingga guru dapat secara langsung memantau perkembangan peserta didik, dan memberikan tugas dengan jangka waktu yang telah ditentukan pada saat pembelajaran secara daring, sehingga dapat sedikit mengurangi kendala yang dihadapi oleh guru.

\section{KESIMPULAN}

Berdasarkan hasil penelitian yang peneliti lakukan di SDN 3 Pelangan melalui wawancara dan dokumentasi, terkait: 
Kesulitan dalam perencanan pembelajaran daring matematika, (2) Kesulitan dalam pelaksanaan pembelajaran daring matematika, dan (3) Kesulitan dalam evaluasi pembelajaran daring matematika. Maka dapat ditarik kesimpulan bahwa:

Kesulitan dalam perencanan pembelajaran daring matematika terdapat dua kesulitan yakni kesulitan pada pemilihan media pembelajaran daring matematika dan kesulitan dalam fasilitas pembelajaran daring matematika, adapun kesulitan dalam fasilitas meliputi kesulitan pada handphone android, kesulitan pada kuota internet, dan kesulitan pada koneksi jaringan.

Kesulitan dalam pelaksanaan pembelajaran daring matematika yang dirasakan oleh guru kelas V di SDN 3 pelangan yakni kesulitan pada mengordinasi peserta didik pada saat pelaksanaan pembelajaran daring maematika berlangsung. Yang menjadi faktor penghambat dalam kesulitan ini dikarenakan guru tidak dapat secara langsung dan secara leluasa dalam memantau peserta didik selama pelaksanaan pembelajaran daring matematika, dan cara guru mengatasi kesulitan ini ialah dengan melaksanakan pembelajaran secara luring seminggu sekali dengan membentuk kelompok kecil.

Kesulitan dalam evaluasi hasil belajar peserta didik dalam pembelajaran daring matematika ialah pada saat melakukan penilaian. Faktor penghambat guru dalam melakukan penilaian dikarenakan guru tidak mengetahui kebenaran kemampuan siswa dalam mengerjakan semua tugas matematika yang diberikan secara daring. Adapun cara guru mengatasi kendala atau kesulitan ini ialah dengan melakukan penilaian pada saat pembelajaran secara luring dan memberikan tugas dengan jangka waktu yang telah ditentukan pada saat pembelajaran secara daring.

\section{SARAN}

Guru memiliki peran utama dalam membimbing peserta didik dalam suatu proses pembelajaran. Guru yang professional hendaknya memiliki beberapa kompetensi agar pembelajaran menjadi lebih maksimal yakni kompetensi pedagogik, kompetensi kepribadian, kompetensi pofesional, dan kompetensi sosial. Sedangkan bagi peserta didik, dimana semangat dari peserta didik pada saat pelaksanaan pembelajaran juga sangat mempengaruhi hasil belajar peserta didik. Sehingga diharapkan semangat belajar dari peserta didik juga mendukung, dan bagi orang tua salah satu kewajiban orang tua pada anak adalah mendukung kegiatan belajar anak, salah satunya seperti memfasilitasi pelaksanaan belajar anak, membimbing anak ketika belajar dirumah, dan lain sebagainya, sehingga dukungan orang tua dalam pelaksanaan kegiatan belajar mengajar juga sangat dibutuhkan.

\section{DAFTAR PUSTAKA}

Andriani, Rita. 2020. Evaluasi Pembelajara Online Matematika Siswa Kelas 5 SD Negeri 5 Metro Pusat. Skripsi S1. IAIN Metro.

Hamdani, Acep Roni. 2020. Efektifitas Implementasi Pembelajaran Daring (Full Online) Dimasa Pandemi Covid19 pada Jenjang Skolah Dasar di Kabupaten Subang. Jurnal Ilmiah PGSD STKIP Subang : 1-9.

Mardawani. 2020. Praktis Penelitian Kualitatif.

Yogyakarta: CV. Budi Utama.

Bengkulu Utara. Skripsi Institut Agama Islam Negeri Bengkulu.

Rahmawati, Septiana Dwi. 2009. Kendala Pelaksanaan Pembelajaran Jarak Jauh Melalui Internet pada Mahasiswa PJJ SI PGSD Universitas Negeri Semarang. Skripsi SI Universitas Negeri Malang.

Rigianti, Henry Aditia. 2020. Kendala Pembelajaran Daring Guru Sekolah Dasar di Kabupaten Banjarnegara. Jurnal Elementary School. 297-302.

Setyowati, Luluk \& Septiani, Eka. 2020. Penggunaan Media Secara Daring Terhadap Pemahaman Belajar Mahasiswa. Jurnal. 121-128.

Utami, Yuliza Putri. 2020. Analisis Kesulitan Belajar Matematika pada Proses Pembelajaran Daring. Jurnal Ilmiah Matematika Realistik. 20-26. 